\title{
Management of Potato Tuber Moth during Storage by using Biological Agents in Hassan District of Karnataka
}

\author{
P. S. Prasad", H. Amarananjundeswara, Soumya Shetty, G. C. Sandhya, \\ Vishnuvardhana N. Basavaraj and G. K. Ramegowda
}
All India Co-ordinated Research Project on Potato, Horticulture Research and Extension Center, Hassan, Karnataka, India- 573219

*Corresponding author

\author{
A B S T R A C T
}

\section{Ke y w o r d s}

Kufri Jyoti, Tuber, Potato Tuber Moth and Dip treatment

Article Info

Accepted:

07 August 2020

Available Online:

10 September 2020
An experiment was conducted for three consecutive years from 2016 to 2018 during Rabi season at Horticulture Research and Extension Center, Hassan, Karnataka. A study was conducted by using Complete Block Design with four replications under storage. For PTM management studies, Kufri Jyoti tubers were planted at $60 \mathrm{~cm} \mathrm{X} 20 \mathrm{~cm}$ spacing with soil application of recommended dose of fertilizers (75:75:100 kg NPK/ha) and FYM (25 t/ha) during Kharif season as per package of practices. After harvesting of Kharif season crop, tubers were dipped with neem oil and Bt formulations at different concentrations were evaluated. The per cent incidence of tuber damage due to PTM was documented at monthly intervals for four months under room temperature conditions. The pooled data of three years indicated that, out of five treatments Bt formulation @ 2 per cent concentration noticed lowest per cent mean incidence of tuber damage of 24.05 followed by $\mathrm{Bt}$ formulation@1 per cent concentration was revealed 29.30 per cent mean incidence of tuber damage. Hence, dip treatment of tubers with Bt formulation @ 2 per cent was found to be effective for post harvest management through biological control of potato tuber moth damage under storage in Southern Dry Zone of Karnataka in India.

\section{Introduction}

Potatoes are liable to infestation by many insect pests, which reduce yield, quantity and quality. Potato tuber moth (PTM), Phthorimaea operculella (Zeller) is the most economically significant potato pest in the mid hills and plateau areas of India (Chandla and Verma, 2000). The potato tuber moth is a world-wide pest of potato and other solanaceous vegetables (Mandour et al., 2012).
An infestation in the stores starts mostly through freshly harvested infested tubers or through moths entering the storage facilities. The larvae of PTM mine in tubers making them unsuitable for sale and consumption. The damage increases rapidly, when several generations develop during the storage period. The larvae are capable of causing damage on potato crop either in the field or in the stores. The synthetic chemical pesticides have been used for many years to control agricultural 
insect pests including those that damage durable food crops in storage. However, considerable problem may arise from the continuous application of these insecticides, including the development of resistance by insects, pollution of environment and hazards from handling toxic compounds (MeyerBaron et al., 2015). Thus, there is a need to develop alternatives that are cheap, locally available, easy to be prepared and safe for insect management. In many areas of the world, there are locally available materials that could be used to protect stored potato and their products against damage by insect infestations. There is a general concern to reduce pesticide use and finding alternate PTM control strategies and to integrate them for effective management of the infestation.

The dry formulations containing the bacterium, Bacillus thuringiensis Berliner ssp. kurstaki (Btk), also have been tested for potato tuber moth control in non-refrigerated stores with success (Salama and Salem, 2000). The bio-pesticides generally have several advantages compared to conventional pesticides. Many plant extracts have also been tested to reduce PTM damage in potato stores. Farmers often home-store their potatoes in rustic stores and frequently cover the potato piles using local plants to prevent PTM damage. The beneficial effect of such treatments, often based on local traditional knowledge has been proven in many studies (Ibrahim, 2008). Therefore, the present study was carried out to study the effectiveness of biological agents to control potato tuber moth menace in rustic stores.

\section{Materials and Methods}

An experiment was conducted for three consecutive years from 2016 to 2018 during Rabi season at Horticulture Research and Extension Center, Hassan, Karnataka. A study was conducted by using Complete Block Design with four replications under storage.
For PTM management studies, Kufri Jyoti tubers were planted at $60 \mathrm{~cm} \mathrm{X} 20 \mathrm{~cm}$ spacing with soil application of recommended dose of fertilizers (75:75:100 kg NPK/ha) and FYM (25 t/ha) during Kharif season as per package of practices of UHS, Bagalkot. After harvesting of Kharif season crop, tubers were dipped with different biological agents.

\section{The treatments are as follows}

T1: Untreated Control

T2:Dip treatment of tubers with neem oil @ 1 per cent

T3: Dip treatment of tubers with neem oil @ 2 per cent

T4: Dip treatment of tubers with Bt formulation@ 1 per cent

T5: Dip treatment of tubers with Bt formulation @ 2 per cent

\section{Per cent incidence of potato tuber damage} due to PTM

The number of infested tubers was counted at different intervals up to four months after treatment and calculated the per cent tubers damaged. The per cent incidence of tuber damage due to PTM was documented at monthly intervals for four months under room temperature conditions.

\section{Statistical analysis}

A significance test was adopted by analysis of variance (ANOVA) for Complete Block Design. The ANOVA was carried out using the General Linear Model of the SAS procedure of version 9.1 (Anon, 2007). For factors showing significant effects, mean comparisons were made using the Duncan's Multiple Range Test (DMRT) at 5 per cent level of significance.

\section{Results and Discussion}

The data (Table 1) showed that under storage conditions, different concentrations of 
biological agents were statistically differed and superior over control (57.87\% tuber infestation) in preventing the damage to potato tubers by PTM, Among the treatments, Bt formulation@2 per cent concentration registered lowest per cent mean incidence of tuber damage of 23.01 during 2016. Similarly, during 2017 least PTM damage incidence of about 24.96 per cent was noticed in tuber dip treatment of Bt formulation @ 2 per cent concentration over control $(62.25 \%)$ (Table 2). Whereas, in 2018 tuber dip treatment of Bt formulation @2 per cent concentration recorded 24.19 per cent tuber damage over control (51.56\%) (Table 3; Fig. 1 and 2).

Table.1 Management of potato tuber moth using bio- control agents during 2016

\begin{tabular}{|c|c|c|c|c|c|c|}
\hline \multirow[t]{2}{*}{ Treatments } & \multicolumn{5}{|c|}{ Per cent incidence of tuber damage due to PTM } & \multirow{2}{*}{$\begin{array}{l}\text { Tuber damage } \\
\text { reduction over } \\
\text { control }(\%)\end{array}$} \\
\hline & $1^{\text {st }}$ Month & $2^{\text {nd }}$ Month & $3^{\text {rd }}$ Month & $4^{\text {th }}$ Month & Mean & \\
\hline T1: Untreated Control & 32.55 & 46.19 & 59.80 & 92.92 & 57.87 & 0.00 \\
\hline $\begin{array}{l}\text { T2:Dip treatment of tubers } \\
\text { with neem oil @ } 1 \%\end{array}$ & 14.34 & 34.35 & 45.68 & 80.50 & 43.72 & 24.45 \\
\hline $\begin{array}{l}\text { T3: Dip treatment of tubers } \\
\text { with neem oil @ } 2 \%\end{array}$ & 11.91 & 28.34 & 35.14 & 72.28 & 36.92 & 36.20 \\
\hline $\begin{array}{l}\text { T4: Dip treatment of tubers } \\
\text { with Bt formulation @ 1\% }\end{array}$ & 9.84 & 19.24 & 28.30 & 57.85 & 28.81 & 50.22 \\
\hline $\begin{array}{l}\text { T5: Dip treatment of tubers } \\
\text { with Bt formulation @ 2\% }\end{array}$ & 8.42 & 18.33 & 24.28 & 41.00 & 23.01 & 60.24 \\
\hline SEM +/- & 1.95 & 2.45 & 2.75 & 2.89 & & - \\
\hline CD@ $5 \%$ & 5.80 & 7.28 & 8.18 & 8.58 & & - \\
\hline CV\% & 12.85 & 16.17 & 13.89 & 8.56 & & - \\
\hline
\end{tabular}

Table.2 Management of potato tuber moth using bio- control agents during 2017

\begin{tabular}{|c|c|c|c|c|c|c|}
\hline \multirow[t]{2}{*}{ Treatments } & \multicolumn{5}{|c|}{ Per cent incidence of tuber damage by PTM } & \multirow{2}{*}{$\begin{array}{l}\text { Tuber } \\
\text { damage } \\
\text { reduction over } \\
\text { control }(\%)\end{array}$} \\
\hline & $1^{\text {st }}$ Month & $2^{\text {nd }}$ Month & $3^{\text {rd }}$ Month & $4^{\text {th }}$ Month & Mean & \\
\hline T1: Untreated Control & 36.34 & 50.62 & 70.61 & 91.42 & 62.25 & 0.00 \\
\hline $\begin{array}{l}\text { T2:Dip treatment of tubers } \\
\text { with neem oil @ } 1 \%\end{array}$ & 22.57 & 35.81 & 51.48 & 80.37 & 47.56 & 23.60 \\
\hline $\begin{array}{l}\text { T3: Dip treatment of tubers } \\
\text { with neem oil @ } 2 \%\end{array}$ & 18.36 & 30.98 & 40.82 & 61.52 & 37.92 & 39.08 \\
\hline $\begin{array}{l}\text { T4: Dip treatment of tubers } \\
\text { with Bt formulation @ } 1 \%\end{array}$ & 12.10 & 24.77 & 32.97 & 51.50 & 30.34 & 51.26 \\
\hline $\begin{array}{l}\text { T5: Dip treatment of tubers } \\
\text { with Bt formulation @ } 2 \%\end{array}$ & 8.75 & 18.07 & 29.33 & 43.68 & 24.96 & 59.90 \\
\hline SEM +/- & 0.91 & 0.81 & 1.54 & 1.87 & & - \\
\hline CD@ $5 \%$ & 2.72 & 2.41 & 4.57 & 5.55 & & - \\
\hline CV \% & 10.08 & 5.27 & 7.00 & 5.84 & & - \\
\hline
\end{tabular}


Table.3 Management of potato tuber moth using bio- control agents during 2018

\begin{tabular}{|c|c|c|c|c|c|c|}
\hline \multirow[t]{2}{*}{ Treatments } & \multicolumn{5}{|c|}{ Per cent incidence of tuber damage due to PTM } & \multirow{2}{*}{$\begin{array}{l}\text { Tuber damage } \\
\text { reduction over } \\
\text { control }(\%)\end{array}$} \\
\hline & $1^{\text {st }}$ Month & $2^{\text {nd }}$ Month & $3^{\text {rd }}$ Month & $4^{\text {th }}$ Month & Mean & \\
\hline T1: Untreated Control & 32.00 & 39.75 & 54.25 & 80.25 & 51.56 & 0.00 \\
\hline $\begin{array}{l}\text { T2:Dip treatment of tubers } \\
\text { with neem oil @ } 1 \%\end{array}$ & 25.00 & 29.25 & 47.75 & 64.50 & 41.63 & 19.26 \\
\hline $\begin{array}{l}\text { T3: Dip treatment of tubers } \\
\text { with neem oil @ } 2 \%\end{array}$ & 22.25 & 26.25 & 34.50 & 60.50 & 35.88 & 30.41 \\
\hline $\begin{array}{l}\text { T4: Dip treatment of tubers } \\
\text { with Bt formulation @ 1\% }\end{array}$ & 19.25 & 23.75 & 31.75 & 40.25 & 28.75 & 44.24 \\
\hline $\begin{array}{l}\text { T5: Dip treatment of tubers } \\
\text { with Bt formulation @ } 2 \%\end{array}$ & 17.00 & 20.25 & 26.00 & 33.50 & 24.19 & 53.08 \\
\hline S. Em \pm & 1.80 & 2.60 & 3.64 & 4.17 & & - \\
\hline CD@ $5 \%$ & 5.35 & 7.74 & 10.82 & 12.40 & & - \\
\hline CV\% & 16.62 & 12.81 & 10.88 & 13.28 & & - \\
\hline
\end{tabular}

Table.4 Management of potato tuber moth using bio- control agents during 2016 to 2018

\begin{tabular}{|l|c|c|c|c|c|}
\hline \multirow{2}{*}{ Treatments } & \multicolumn{3}{|c|}{ Incidence of tuber damage (\%) } & Mean & $\begin{array}{l}\text { Tuber } \\
\text { damage } \\
\text { reduction over } \\
\text { control (\%) }\end{array}$ \\
\cline { 2 - 6 } & $\mathbf{2 0 1 6}$ & $\mathbf{2 0 1 7}$ & $\mathbf{2 0 1 8}$ & & \\
\hline T1: Untreated Control & 57.87 & 62.25 & 51.56 & 57.23 & 0.00 \\
\hline $\begin{array}{l}\text { T2:Dip treatment of tubers } \\
\text { with neem oil @ 1 \% }\end{array}$ & 43.72 & 47.56 & 41.63 & 44.30 & 22.58 \\
\hline $\begin{array}{l}\text { T3: Dip treatment of tubers } \\
\text { with neem oil @ 2 \% }\end{array}$ & 36.92 & 37.92 & 35.88 & 36.91 & 35.51 \\
\hline $\begin{array}{l}\text { T4: Dip treatment of tubers } \\
\text { with Bt formulation @ 1\% }\end{array}$ & 28.81 & 30.34 & 28.75 & 29.30 & 48.80 \\
\hline $\begin{array}{l}\text { T5: Dip treatment of tubers } \\
\text { with Bt formulation @ 2\% }\end{array}$ & 23.01 & 24.96 & 24.19 & 24.05 & 57.97 \\
\hline
\end{tabular}

Fig.1 Best treatments

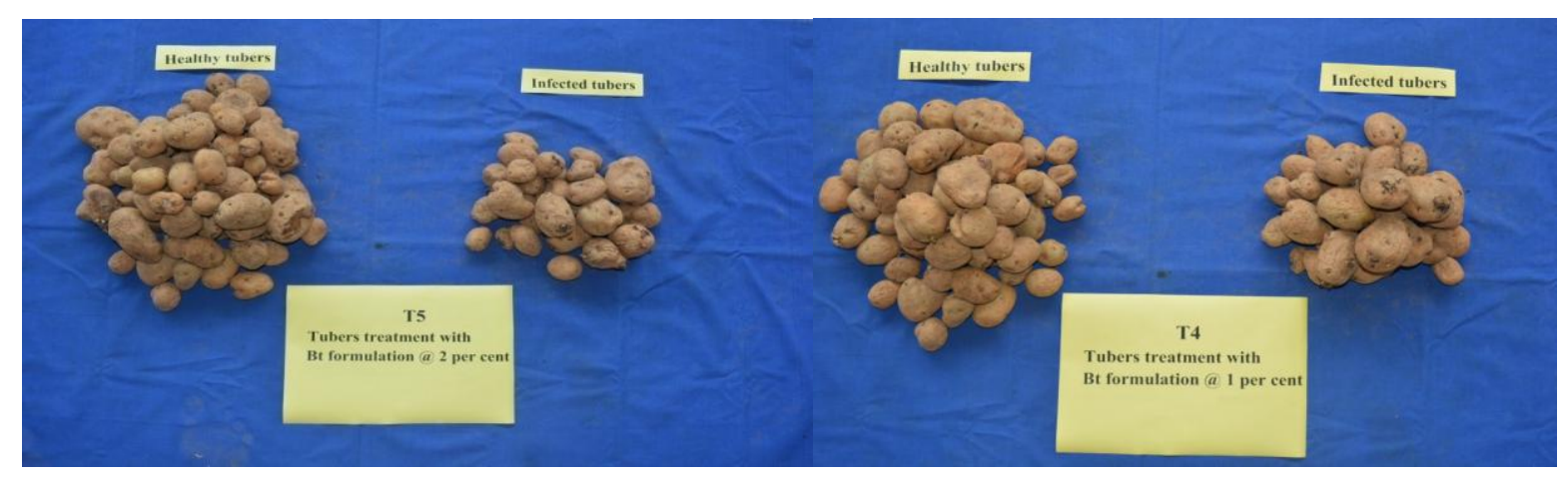


Fig.2 Potato tubers infested with potato tuber moth

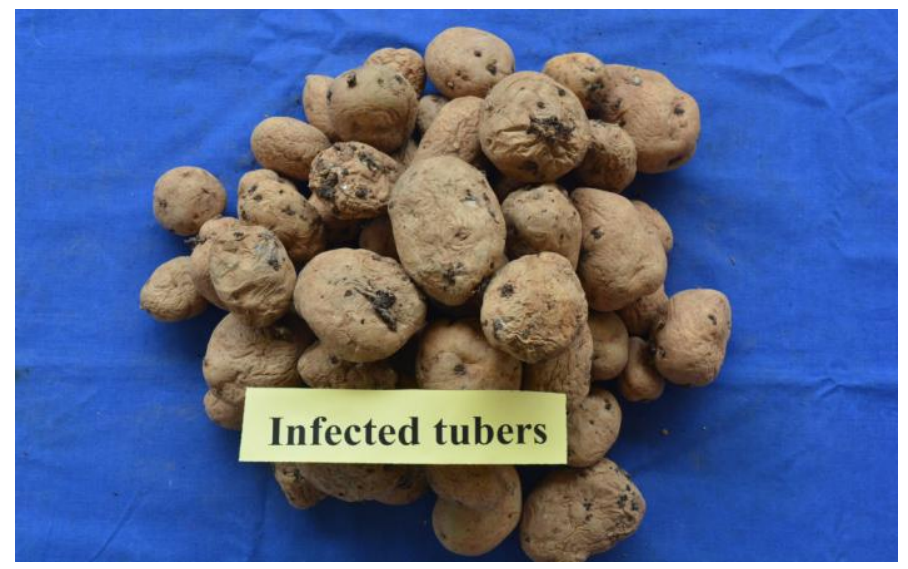

The pooled data of three years indicated that, out of six treatments Bt formulation @ 2 per cent concentration noticed lowest per cent mean incidence of tuber damage of 24.05 followed by Bt formulation @ 1 per cent concentration was revealed 29.30 per cent mean incidence of tuber damage over control $(57.23 \%)$. However, with respect to tuber damage reduction over control, the treatment with Bt formulation @ 2 per cent of dip treatment of tubers resulted in maximum reduction in tuber damage of 57.97 per cent followed by $\mathrm{Bt}$ formulation @ 1 per cent $(48.80 \%)$. Whereas, untreated tubers under storage revealed 100 per cent potato tuber moth damage (Table 4). An efficacy of Btk has been reported against PTM infestations by Arthurs et al., (2008). Bt has also been widely tested to control PTM infestations under laboratory and storage conditions. Under laboratory conditions, PTM larvae are susceptible at differing degrees to various $\mathrm{Bt}$ sub species including kurtaki, thuringiensis, tolworthi, galleriae, kenyae and aizawai, although the lethal concentration required increases with larval age (Salama et al., 1995). In Egypt, another $\mathrm{Bt}$ preparation (Dipel 2X with $32000 \mathrm{IU} / \mathrm{mg}$ at $0.3 \%$ ) was also reported to be very effective in protecting tubers in stored, PTM infestation was eliminated compared with 100 per cent infestation in untreated control at 60 days after treatment (Farrag, 1998). In Tunisia, an integrated control approach comprising $B t$ applied at the beginning of the storage period in combination with cultural control (early harvest) eliminated the reliance on parathion sprays (Von Arx et al., 1987). Bt also proved to be very effective in controlling the other species of the potato tuber moth complex, namely APTM and GPTM (Kroschel et al., 2009).

In conclusion the potato tuber moth is a serious pest of potato especially in stores, where the use of biological agents is an environmentally sound alternative to chemical pesticides. Hence, dip treatment of tubers with Bt formulation@2 per cent was found to be effective for post harvest management of potato tuber moth under storage in Southern Dry Zone of Karnataka in India.

\section{References}

Anonymous, 2007. Statistical Analytical Systems SAS / STAT user's guide version 9(1) Cary NC: SAS institute inc.

Arthurs, S. P., Lacey, L. A., Pruneda, J. N., and Rondon, S. I., 2008. Semi-field evaluation of a granulovirus and Bacillus thuringiensis ssp. kurstaki for season-long control of the potato tuber 
moth, Phthorimaea operculella. Entomol Exp. Appl. 129: 276-85.

Chandla, V. K., and Verma, K. D., 2000. Potato virus vectors and their management. In: Potato, Global Research and Development- Vol.1, Indian Potato Association, CPRI, Shimla. pp. 363-69.

Farrag, R. M., 1998. Control of the potato tuber moth Phthorimaea operculella Zeller (Lepidoptera, Gelechiidae) at storage. Egyptian Journal of Agriculture Research. 76: 947-952.

Ibrahim, M. Y., 2008. Study of effect of temperatures on the natural death and the biotic potential of potato tuber moth, Phthorimaea operculella (Zeller), (Lepidoptera: Gelechiidae) and use of some plant extracts as insect repellents against potato tuber moth under laboratory conditions. Dirasat Agric Sci. 35: 1-10.

Kroschel, J., Sporleder, M., Alcazar, J., Cafiedo, V., Mujica, N., Zegarra, O., and Simon, R., 2009. Challenges and opportunities for potato pest management in developing countries. In: Potato Science for the PoorChellenges for the New Millennium. A working Conference to Celebrate the International Year of the Potato, Cuzco, Peru, 25-28, March 2008.

Mandour, N. S., Sarhan, A., Atwa, H., and Soliman, D. M., 2012. The integration between Trichogramma evanescens Westwood

(Hymenoptera:

Trichogrammatidae) and selected bio insecticides for controlling the potato tuber moth Phthorimaea operculella (Zeller) (Lepidoptera: Gelechiidae) of stored potatoes. J. Plant Prot. Res. 52 (1): 40-46.

Meyer Baron, M., Knapp, G., Schaper, M., and Van Thriel, C., 2015. Metaanalysis on occupational exposure to pesticides-neyro behavioral impact and dose response relationships. Environ Res. 136:234-245.

Salama, H. H., Ragaei, M., and Sabbour, M., 1995. Larvae of Phthorimaea operculella (Zell.) as affected by various strains of Bacillus thuingiensis. Journal of Applied Entomology. 119: 241-243.

Salama, H. S., and Salem, S. A., 2000. Bacillus thuringiensis and neem seed oil (Azadirachta indica) effects on the potato tuber moth Phthorimaea operculella Zeller in the field and stores. Arch Phytopathol Plant Prot. 33: 73-80.

Von Arx, R., Goueder, J., Cheikh, M.. and Temime, A. B., 1987. Integrated control of potato tuber moth Phthorimaea operculella (Zell.) in Tunisia. Insect Science and its Application. 8: 989-994.

\section{How to cite this article:}

Prasad, P. S., H. Amarananjundeswara, Soumya Shetty, G. C. Sandhya, Vishnuvardhana N. Basavaraj and Ramegowda, G. K. 2020. Management of Potato Tuber Moth during Storage by using Biological Agents in Hassan District of Karnataka. Int.J.Curr.Microbiol.App.Sci. 9(09): 465-470. doi: https://doi.org/10.20546/ijcmas.2020.909.059 